Egyptian Journal of Rabbit Science, 25(1): 39 - 57(2015)

\title{
NANO-COPPER AS A NEW GROWTH PROMOTER IN THE DIET OF GROWING NEW ZEALAND WHITE RABBITS
}

\author{
Amira M. Refaie ${ }^{1}$; Mervat N. Ghazal'; Fadila M. Easa'; Safaa A. \\ Barakat $^{1}$; Morsy W.A. ${ }^{1}$; Samia Z. Meshreky ${ }^{1}$ Younan G. E. ${ }^{1}$ and \\ Eisa W.H. ${ }^{2}$ \\ ${ }^{1}$ Animal Production Research Institute, ARC, Dokki, Giza, 12618, Egypt \\ ${ }^{2}$ National Research Center, Dokki, Giza, Egypt. \\ Corresponding Author: amira_refaie2@yahoo.com
}

Seventy two rabbits, 35 days old and weighing $622 \mathrm{~g}$ average body weight, were used for the present study. The rabbits were randomly assigned into 4 equal treatments $(n=18)$. Animals in treatment 1 served as a control group and were given basal diet without supplementation, while rabbits in treatments 2, 3 and 4 were given nano-copper in the diet at levels 25, 50 and $75 \mathrm{mg} / \mathrm{kg}$ diet, respectively. The experiment lasted for 8 weeks.

The results revealed that, rabbits fed diets supplemented with 50 or $75 \mathrm{mg} \mathrm{Cu} / \mathrm{kg}$ diet as Nano-Cu recorded significantly higher $(P<0.01)$ final body weight and performance index also, recorded better feed conversion ratio during all growth periods than the control group. The group of rabbits fed diet supplemented with $50 \mathrm{mg}$ Nano$\mathrm{Cu} / \mathrm{kg}$ diet significantly achieved the best relative growth rate percentage. Dietary supplementation with $50 \mathrm{mg} \mathrm{Nano-Cu} / \mathrm{kg}$ diet significantly recorded higher carcass, fore part, trunk and hind part percentages comparing with the control group, it also significantly reduced abdominal fat by $28.4 \%$. The Nano- $\mathrm{Cu}$ supplementation significantly $(P<0.05)$ increased activity of superoxide dismutase enzyme compared with the control group. Copper content in rabbits liver significantly increased by increasing dietary Nano-Cu.

Dietary Nano-Cu supplementation significantly $(P<0.05)$ increased the population of total bacterial count and lactolacillus counts and decreased the population of ureolytic bacteria, Escherichia coli and clostridium spp. Supplementation of Nano-Cu to rabbit diets significantly increased plasma hemoglobin, red blood cells count and lymphocytes percentage. Economical efficiency 
improved for rabbits fed either 50 or $75 \mathrm{mg}$ Nano-Cu supplemental diet.

Conclusively, Nano-Cu is considered a new substitution for high dose of inorganic copper in growing NZW rabbits feeding and can be fed up to $50 \mathrm{mg} / \mathrm{kg}$ diet without any deleterious effects on production and meat safety of rabbits.

Keywords: Nano-copper, growth promoter, growing rabbits, productive performance.

Mortality rate in growing rabbits is about $30 \%$ throughout the year mostly occur after post-weaning during 5-10 weeks of age as reported by Nikkels et al. (1976). This problem may be due to non-specific enteropathy arise in weaned rabbits. Many studies Laurence et al. (2003) and Alves et al. (2004) revealed a reduction in villous height and either an increase or decrease in crypt depth. This is possible due to contributions of local inflammatory reactions to villus-crypt during the weaning (McCracken et al., 1999). Also, the activity of the digestive enzymes in pancreatic tissue is low after 5 days post weaning due to interaction with other factors which may increase the risk of developing post-weaning diarrhea (Hedemann and Jensen, 2004).

Copper is an essential trace element, and plays a vital role in the physiology of animals for feotal growth and early postnatal development, bone maturation and haemoglobin formation (McDowell, 1992 and McDonald et al.,2002). Although copper is not essentially a constituent of haemoglobin, it is present in certain other plasma proteins such as ceruloplasmin, which is concerned with the release of iron from the cell into the plasma McDonald et al. (2002), and Adu and Egbunike (2010) reported that copper added at levels higher than normal requirement has a growth promoting effect because copper inhibit intestinal harmful microbs, thus it has function to stimulate growth and improve feed efficiency (Shurson et al., 1987).

Dietary copper supplementation at levels of 200 to $300 \mathrm{mg} / \mathrm{kg}$ caused a growth enhancement effect, particularly in weaned rabbits (Onifade and Abu, 1998 and Aboul-Ela et al., 2000). Also, Adu et al. (2010) found that dietary copper level up to $300 \mathrm{mg} / \mathrm{kg}$ improved feed intake, and weight gains in growing rabbits. However, (McDowell, 1992) noticed that when dietary copper level was high, its absorption low, because large amounts of 
copper is excreted in the feces. According to European Union Commission Health (2003) recommended the maximum concentration of copper allowed in rabbit diets has been restricted to $35 \mathrm{mg} / \mathrm{kg}$. Copper nano particle is one of the nano metal which is recently prepared for application in various fields, so we suppose that if the copper absorption is enhanced the copper supplementation and excretion levels may be reduced. Gonzales-Eguia et al. (2009) concluded that the growth performance of piglets fed diets supplemented with $50 \mathrm{mg}$ Nano-Cu/kg diet showed significant improvement in growth performance and copper availability. Also, Lien (2009) found that the bioavailability of copper improved in pigs fed diets supplemented with $50 \mathrm{mg}$ Nano-Cu/kg diet. In broilers, Wang et al. (2011) showed that supplementation of Nano-Cu at level of 50 or $100 \mathrm{mg} / \mathrm{kg}$ diet improves growth performance, strengthen the immune system, enhance protein synthesis and activates the cecal microbiota.

Studies so far have indicated that the application of nano minerals in animal production and immunity is promising. However, application of nano minerals in this field is immense (Rajendran, 2013). The safety aspects of application of nano-minerals need to be addressed before being applied.

Therefore, this study aimed to evaluate the impact of dietary supplementation of Nano-Cu at different levels on productive and physiological performance of growing NZW rabbits and determine the food safety by testing copper residue on edible organ (liver) and muscles. Finally, to determine the best and beneficial level that would improve rabbit performance.

\section{MATERIALS AND METHODS}

The present study was carried out at Sakha Research Station, Animal Production Research Institute, Agriculture Research Center, Egypt.

\section{Preparation of nano copper:}

The colloid of copper nanoparticles was prepared at room temperature using $\mathrm{Cu}\left(\mathrm{NO}_{3}\right)_{2}$. $3 \mathrm{H}_{2} \mathrm{O}$ (S.d. Fine-Chem. Ltd) as a source for $\mathrm{Cu}$ metal. Typically, $2.41 \mathrm{gm}$ of $\mathrm{Cu}$ precursor were added to $100 \mathrm{ml}$ solution of $75 \mathrm{ml}$ deionized water and $25 \mathrm{ml}$ ethylene glycol under strong magnetic stirring. The deep blue solution was subjected to additional stirring for $30 \mathrm{~min}$ to attain higher homogeneity. Thereafter, $300 \mu \mathrm{l}$ of ice cold (1 M) NaBH4 (Merck) was quickly injected into the above mixture. The solution turned 
colorless after about $1 \mathrm{~min}$, and then turned burgundy, indicating the growth of $\mathrm{Cu}$ nanoparticles, Zhang et al. (2009). The copper content of Nano- $\mathrm{Cu}$ was $37.38 \%$, which was determined by flame atomic absorption spectrometry (Perkin-Elmer Analyst 100: Flame Atomic Absorption spectrometry).

\section{Animals and experimental design:}

A total number of seventy two NZW weaned rabbits at five weeks of age (average weight $622 \mathrm{~g}$ ) were divided equally into four treatments. Each group contained 18 rabbits. The experimental period extended from 5 to 13 weeks of age. The four groups were as follows: The control group, received basal diet without nano copper supplementation, while groups 2, 3 and 4 received basal diet with 25,50 and $75 \mathrm{mg}$ nano copper/kg diet, respectively.

Diet was pelleted and formulated to meet the recommended nutrient requirements of rabbits according to NRC (1977). Composition and calculated analysis of the basal experimental diet was presented in Table 1. Feed was provided ad libitum. Fresh water was available from automatic drinkers with nipples for each cage. All rabbits were observed daily, kept under the same managerial, hygienic and environmental condition, and vaccinated against common diseases.

Live body weights (BW) were recorded individually at the beginning of the experiment (5 weeks of age) and every two weeks till the end of the experiment (13 weeks of age). Daily weight gains (DWG) were calculated. Feed intake (FI) was recorded, while feed conversion ratios (FCR) and, relative growth rate (RGR) was calculated according to the following equation:

Relative growth rate $=[(\mathrm{W} 2-\mathrm{W} 1) \times 100] /[1 / 2(\mathrm{~W} 2+\mathrm{W} 1)]$

Whereas: $\mathrm{W} 1=$ The initial body weight $(\mathrm{g})$, and $\mathrm{W} 2=$ The final body weight $(\mathrm{g})$.

Performance index $(\mathrm{PI})=($ Final live body weight $(\mathrm{kg}) /$ Feed conversion ratio) $\times 100$, according to North $(1981)$.

\section{Carcass traits and Blood constitutes :}

At the end of the experimental period, three animals randomly were taken from each group and slaughtered to study carcass characteristics. Head, heart, kidneys and liver were weighed and carcass percentage was calculated according to Cheeke (1987).

Rabbits blood samples were taken into tubes with anticoagulant (heparin) and centrifuged at $3000 \mathrm{rpm}$ for 5 minutes and plasma were stored at $-20^{\circ} \mathrm{C}$ until analysis for determination of catalase enzyme, whole blood Superoxide dismutase (SOD) activities and plasma copper concentration. 
NANO-COPPER AS A NEW GROWTH PROMOTER IN DIET RABBITS 43

Table 1: Ingredients composition (\%) and calculated analysis of the basal experimental diet.

\begin{tabular}{|c|c|c|c|}
\hline Ingredients & $\%$ & \multicolumn{2}{|c|}{ Calculated analysis $* *$} \\
\hline Yellow corn & 4.10 & DE, kcal/kg & 2517 \\
\hline Soybean meal (44\%) & 6.97 & Crude protein $\%$ & 16.09 \\
\hline Soybean meal (48\%) & 3.00 & Crude fat $\%$ & 2.28 \\
\hline Wheat bran & 34.25 & Crude fiber $\%$ & 14.15 \\
\hline Clover hay & 36.29 & Total P \% & 0.80 \\
\hline Barley grains & 8.32 & Lysine \% & 0.70 \\
\hline DL. Methionine & 0.28 & Methionine \% & 0.37 \\
\hline Molasses & 4.00 & Methionine + Cys. & 0.60 \\
\hline L. lysine $\mathrm{Hcl}$ & 0.19 & & \\
\hline Lime stone & 0.70 & & \\
\hline Di calcium phosphate & 1.20 & & \\
\hline $\mathrm{NaCl}$ & 0.30 & & \\
\hline *Vit. and Min. Mixture. & 0.30 & & \\
\hline Anticoccedial & 0.10 & & \\
\hline Total & 100 & & \\
\hline \multicolumn{4}{|c|}{$\begin{array}{l}\text { * Each } 3 \text { kg contain: } 6000000 \mathrm{IU} \text { Vit. A; } 900000 \mathrm{IU} \text { Vit. } \mathrm{D}_{3} ; 40000 \mathrm{mg} \text { Vit. E; } 2000 \mathrm{mg} \\
\text { Vit. } \mathrm{K}_{3} ; 2000 \mathrm{mg} \text { Vit. } \mathrm{B}_{1} ; 4000 \mathrm{mg} \text { Vit. } \mathrm{B}_{2} ; 2000 \mathrm{mg} \text { Vit. B } ; 10 \mathrm{mg} \text { Vit. } \mathrm{B}_{12} ; 50 \mathrm{mg} \\
\text { Biotin; } 10000 \mathrm{mg} \text { Pantothenic acid; } 50000 \mathrm{Niacin} ; 3000 \mathrm{mg} \text { Folic acid; } 250000 \mathrm{mg} \\
\text { Choline; } 8500 \mathrm{mg} \mathrm{Mn} ; 50000 \mathrm{mg} \mathrm{Zn} ; 50000 \mathrm{mg} \mathrm{Fe} ; 200 \mathrm{mg} \mathrm{I} ; 100 \mathrm{mg} \mathrm{Se}, 5000 \mathrm{mg} \\
\text { Cu, and } 100 \mathrm{mg} \text { Co. } \\
\text { **According to NRC (1977). }\end{array}$} \\
\hline
\end{tabular}

All biochemical constitutes were determined using commercial kits (Biodiagnostic Company, Cairo, Egypt).

\section{Copper analysis:}

Copper analysis was based on the method of Ansari and Raissy(2011). Samples of feces were collected for 7days from three animals/ treatment, and placed in metabolic cages to analyze of total $\mathrm{Cu}$ concentration. Also samples for liver and muscles / each group were analyzed for total $\mathrm{Cu}$ concentration. The samples were prepared for $\mathrm{Cu}$ analysis by digestion in microwave. The determination of $\mathrm{Cu}$ concentration was done by atomic absorption spectrometry (Hitachi, Japan) at the Central Laboratory for Pesticides Residue and Heavy Metals in Food, Agricultural Research Center, Ministry of Agriculture, Egypt. 


\section{Cecum traits:}

Samples of cecum content were taken individually from rabbits of each group and filtrated to estimate $\mathrm{pH}$ and cecum microflora. Total anaerobic bacteria count and Escherichia coli (E. coli) were estimated according to Collins et al. (1995), and lactobacilli bacteria count according to Kim and Goepfert (1971). In addition, cecum $\mathrm{pH}$ was measured by using $\mathrm{pH}$ meter in filtrate cecum content. Ammonia nitrogen concentration was determined as described by Conway (1958).

\section{Haematology analyses:}

Packed cell volume (PCV) was determined by spinning about $75 \mu 1$ of each blood sample in heparinized capillary tube in a haematocrit centrifuge for about 5 minutes and read on haematocrit reader as described by Benson et al. (1989) while erythrocytes (RBC) and leucocytes (WBC) counts and differential white blood counts (neutrophils, eosinophils, basophils, lymphocytes and monocytes) were determined using haemocytometer method as described by Lamb (1981). The haemoglobin $(\mathrm{Hb})$ concentration and the blood constants: mean cell haemoglobin $(\mathrm{MCH})$, mean corpuscular volume (MCV) and mean corpuscular haemoglobin concentration (MCHC) were determined using cyanethaemoglobin method and appropriate formula respectively as described by Jain (1986).

\section{Economical efficiency:}

Feeding economical efficiency (EE) was calculated and carried out according to the prices of feed ingredients, feed additives and rabbits meat prevailing, during year of 2014.

It was calculated as follows: $\mathrm{EE}=\mathrm{Net}$ revenue/ Total feed cost While, Net revenue $=$ Selling price of total weight gain - Total feed cost.

\section{Statistical analysis:}

Data were statistically analyzed according to SAS (2001), using the following fixed model:

$$
\mathrm{Y}_{\mathrm{i}}=\mu+\mathrm{T}_{\mathrm{i}}+\mathrm{e}_{\mathrm{i}}
$$

Where: $Y_{i}=$ The observation; $\mu=$ Overall mean; $T_{i}=$ Effect of treatments ( $i$ $=1,2,3$ and 4$) ; \mathrm{e}_{\mathrm{i}}=$ Random error component assumed to be normally distributed.

Data presented as percentages were transformed to the corresponding arcsine values (Warren and Gregory, 2005) before being statistically analyzed. The differences among means were tested using Duncan's New 
NANO-COPPER AS A NEW GROWTH PROMOTER IN DIET RABBITS 45

Multiple Range Test (Duncan, 1955). All data are presented in least square means form.

\section{RESULTS AND DISCCUSION}

\section{Growth performance:}

Results in Table 2 show that final BW values were significantly $(\mathrm{P}<0.01)$ the highest with rabbits fed diets supplemented with either 50 or $75 \mathrm{mg} \mathrm{Nano}-\mathrm{Cu} / \mathrm{kg}$ diet compared with those fed zero or $25 \mathrm{mg}$ Nano-Cu/ $\mathrm{kg}$ diet. The proportional increments were 4.6 and $2.9 \%$ for the two highest levels, respectively. The same trend was noted in body weight gain either, during 5-9 weeks of age or during the whole growth period (5-13 weeks of age). These results are in agreement with Wang et al. (2011) who showed that dietary supplementation with $100 \mathrm{mg} / \mathrm{kg}$ of copper-loaded chitosan nanoparticle ( $\mathrm{CNP}-\mathrm{Cu})$ increased the average daily body gain in broiler chickens.

The increase in body weight gain may be interpreted through the unique characteristics of nanoparticles might make copper more effective in stimulating activities of some growth factors much better than the control diet or the small amount of Nano-Cu (Du, 2008).

Concerning to rabbits feed intake, it was gradually decreased by increasing Nano-Cu level in the diet during all growth periods. In this concern, Gonzales-Eguia et al., (2009) found that average daily weight and feed/gain ratio were higher in piglets fed diet supplemented with $50 \mathrm{mg}$ Nano- $\mathrm{Cu} / \mathrm{kg}$ diet comparing with the control group and those fed diet supplemented with copper sulphate $(50 \mathrm{mg} / \mathrm{kg}$ diet). also, Wang et al., (2011) reported that the average daily gain of broiler chickens received 100 $\mathrm{mg} / \mathrm{kg}$ of Nano-Cu diets was increased by $6.31 \%(P<0.05)$ during 0 to $21 \mathrm{~d}$, $8.52 \%(P<0.05)$ during 22 to $42 \mathrm{~d}$, and $7.79 \%(P<0.05)$ during 0 to $42 \mathrm{~d}$, in comparison with the control group.

Feed conversion ratio was significantly improved in rabbits fed diets supplemented with $50 \mathrm{mg}$ Nano-Cu/ $\mathrm{kg}$ diet, during all growth periods while, the worst value was recorded in rabbits fed the control diet. The improvement recorded $8.6 \%$ comparing to the control group. These results are in accordance with the studies reported by Patton et al. (1982) and Grobner et al. (1986) who reported that growth performance of rabbits improved as a consequence of copper supplement in the diet or drinking water under tropical conditions, but in contrast with the results obtained by 
AMIRA REFAIE et al.

Table 2: Effect of dietary nano copper supplementation on growth performance of growing NZW rabbits from 5 to 13 wks of age.

\begin{tabular}{|c|c|c|c|c|c|c|}
\hline \multirow{2}{*}{ Parameters } & \multicolumn{4}{|c|}{ Nano copper levels (mg/kg) } & \multirow[b]{2}{*}{ SEM } & \multirow[b]{2}{*}{ Sig. } \\
\hline & $\mathbf{0}$ & 25 & 50 & 75 & & \\
\hline No. of animals & 18 & 18 & 18 & 18 & - & - \\
\hline Initial body weight (g) & 621.50 & 623.50 & 624.00 & 621.80 & 7.72 & NS \\
\hline Final body weight (g) & $1928.30^{\mathrm{b}}$ & $1922.10^{\mathrm{b}}$ & $2017.10^{\mathrm{a}}$ & $1983.30^{\mathrm{a}}$ & 17.91 & $* *$ \\
\hline \multicolumn{7}{|l|}{ Daily weight gain (g): } \\
\hline $5-9$ weeks & $23.99^{\mathrm{b}}$ & $23.87^{\mathrm{b}}$ & $25.95^{\mathrm{a}}$ & $25.29^{\mathrm{ab}}$ & 0.54 & $*$ \\
\hline 9-13 weeks & 22.78 & 22.53 & 23.82 & 23.40 & 0.45 & NS \\
\hline 5-13 weeks & $23.38^{\mathrm{bc}}$ & $23.20^{\mathrm{c}}$ & $24.88^{\mathrm{a}}$ & $24.35^{\mathrm{ab}}$ & 0.37 & $* *$ \\
\hline \multicolumn{7}{|l|}{ Feed intake $(g / d)$ : } \\
\hline 5-9 weeks & $58.96^{\mathrm{a}}$ & $57.63^{b}$ & $57.16^{\mathrm{bc}}$ & $56.03^{\mathrm{c}}$ & 0.46 & $* *$ \\
\hline 9-13 weeks & $99.04^{\mathrm{a}}$ & $97.27^{\mathrm{b}}$ & $96.50^{\mathrm{bc}}$ & $95.36^{\mathrm{c}}$ & 0.49 & $* *$ \\
\hline 5-13 weeks & $79.00^{\mathrm{a}}$ & $77.45^{\mathrm{b}}$ & $76.83^{\mathrm{bc}}$ & $75.69^{c}$ & 0.56 & $* *$ \\
\hline \multicolumn{7}{|l|}{ Feed conversion ratio: } \\
\hline 5-9 weeks & $2.46^{\mathrm{a}}$ & $2.45^{\mathrm{a}}$ & $2.21^{\mathrm{b}}$ & $2.23^{\mathrm{b}}$ & 0.06 & $* *$ \\
\hline $9-13$ weeks & $4.38^{\mathrm{a}}$ & $4.38^{\mathrm{a}}$ & $4.07^{\mathrm{b}}$ & $4.10^{\mathrm{ab}}$ & 0.08 & $*$ \\
\hline 5-13 weeks & $3.39^{\mathrm{a}}$ & $3.36^{\mathrm{a}}$ & $3.09^{\mathrm{b}}$ & $3.12^{\mathrm{b}}$ & 0.05 & $* *$ \\
\hline Relative growth rate(\%) & $102.50^{\mathrm{b}}$ & $102.02^{\mathrm{b}}$ & $105.50^{\mathrm{a}}$ & $104.50^{\mathrm{ab}}$ & 1.46 & $*$ \\
\hline Performance index (\%) & $56.90^{\mathrm{b}}$ & $57.20^{\mathrm{b}}$ & $65.10^{\mathrm{a}}$ & $63.60^{\mathrm{a}}$ & 01.03 & $* *$ \\
\hline Mortality $(\%)^{(1)}$ & 10.00 & 5.00 & 5.00 & 10.00 & - & - \\
\hline
\end{tabular}

Adu (2004) and Adu and Egbunike (2010) who concluded that There was no significant effect of supplementing copper $(\mathrm{P}>0.05)$ on the feed conversion ratio of growing rabbits.

The results obtained of growth performance parameters were confirmed by the value of relative growth rate where, the group of rabbits fed diet supplemented with $50 \mathrm{mg}$ Nano- $\mathrm{Cu} / \mathrm{kg}$ diet was the best group. Shurson et al. (1990) reported that the performance enhancing effect of copper in animals may be achieved through the microbial gut flora as shown by the results of positive effect of high concentrations (283ppm) of copper. It has been reported that copper can be used as a performance enhancer in fresh water-farming because it protects fish from diseases, thereby improving the growth of fish (Berntssen et al., 1999). Copper was reported to improve digestibility and utilization of nutrients in the diets of pigs and broilers which might be achieved through influencing activities of hormones such as growth and thyroid hormones as reported by Underwood and Suttle (1999). 


\section{Carcass characteristics:}

The effect of different levels of supplemental Nano-Cu are shown in Table 3. Comparing with the control, carcass, fore parts, trunk and hind parts percentages in rabbits fed diet supplemented with $50 \mathrm{mg}$ Nano-Cu $/ \mathrm{kg}$ diet were higher by $4.2 \%, 5.7 \%, 4 \%$ and $3.6 \%$, respectively, while, abdominal fat was lower by $28.4 \%$. This may be indicating that $\mathrm{Cu}$ is hypolipolemic and has capability of influencing lipid metabolism Idowu et al. (2011). In this connection Yassein et al. (2011) concluded that dressing, hot carcass weight, leg weight and abdominal fat percentages were significantly improved in rabbits fed diet supplemented with copper comparing to the control group. While, liver weight did not affected significantly by $\mathrm{Cu}$ supplementation. On the other hand, Ayyat et al. (1995) and Bassuny (1991) who reported that carcass traits was insignificantly affected by dietary copper levels in NZW rabbits.

\section{Oxidative enzymes:}

Results in Table 4 indicated that superoxide dismutase enzyme activity was higher in rabbits fed diets supplemented with different levels of Nano-Cu compared with control group. This result is in agreement with Lien (2009) who found that SOD activity in nanocopper supplemental pigs was significantly the highest followed by those fed inorganic copper $\left(\mathrm{CuSO}_{4}\right)$. McDwell (1992) reported that $\mathrm{Cu}$ has an important role in metalloenzyme such as superoxide dismutase (SOD) activity. Also, Gonzales-Eguia et al. (2009) showed that Nano-Cu supplementation significantly increased the SOD activity in the blood serum of piglets. This effect may be due to that nanoparticles with reduced size and greater surface area exhibit a high rate of absorption in the gasterointestinal tract (Hussain et al., 2001). As their small size, the nanoparticles can penetrate through small capillaries and absorbed by the cells (Sahoo and Labhasetwar 2003). Plasma catalase enzyme activity and copper were not affected by Nano-Cu supplementation. On the other hand, these results disagree with these reported by Fahmy et al. (2009) who showed that exposed to copper nanoparticles decreased level of catalase enzyme activity.

\section{Copper residues in liver, muscles and feaces:}

Effect of dietary levels of Nano-Cu on copper residues for NZW rabbits' liver, muscles and feces is shown in Table 4 . Results indicated that liver and feaces copper content were significantly $(\mathrm{P}<0.05$ and 0.01$)$ higher 
AMIRA REFAIE et al.

Table 3: Effect of dietary nano copper supplementation on carcass traits of growing NZW rabbits.

\begin{tabular}{|c|c|c|c|c|c|c|}
\hline \multirow{2}{*}{ Parameters } & \multicolumn{4}{|c|}{ Nano copper levels (mg/kg) } & \multirow[b]{2}{*}{ SEM } & \multirow[b]{2}{*}{ Sig. } \\
\hline & $\mathbf{0}$ & 25 & 50 & 75 & & \\
\hline Carcass, \% & $48.05^{b}$ & $48.36^{b}$ & $50.09^{\mathrm{a}}$ & $49.61^{\mathrm{a}}$ & 0.36 & $* *$ \\
\hline Fore parts , $\%$ & $11.83^{\mathrm{b}}$ & $11.90^{\mathrm{b}}$ & $12.50^{\mathrm{a}}$ & $12.13^{\mathrm{ab}}$ & 0.18 & $*$ \\
\hline Trunk, \% & $17.62^{\mathrm{b}}$ & $17.68^{\mathrm{b}}$ & $18.32^{\mathrm{a}}$ & $18.23^{\mathrm{a}}$ & 0.12 & $*$ \\
\hline Hind parts, \% & $18.60^{\mathrm{b}}$ & $18.78^{b}$ & $19.27^{\mathrm{a}}$ & $19.24^{\mathrm{a}}$ & 0.15 & $*$ \\
\hline Liver, \% & 3.54 & 03.56 & 4.44 & 4.01 & 0.28 & NS \\
\hline Kidney, \% & 0.58 & 0.52 & 0.55 & 0.52 & 0.04 & NS \\
\hline Heart, \% & 0.23 & 0.28 & 0.33 & 0.35 & 0.02 & NS \\
\hline Total edible parts , $\%$ & $52.41^{\mathrm{b}}$ & $52.71^{\mathrm{b}}$ & $55.41^{\mathrm{a}}$ & $54.48^{\mathrm{a}}$ & 0.405 & $* *$ \\
\hline Abdominal fat, $\%$ & $1.34^{\mathrm{a}}$ & $1.20^{\mathrm{a}}$ & $0.96^{\mathrm{b}}$ & $1.22^{\mathrm{a}}$ & 0.053 & $* *$ \\
\hline GIT,$\%^{(1)}$ & $20.61^{\mathrm{a}}$ & $19.39^{\mathrm{b}}$ & $17.89^{\mathrm{c}}$ & $18.90^{\mathrm{bc}}$ & 0.401 & $* *$ \\
\hline
\end{tabular}

Table 4: Effect of dietary nano copper supplementation on oxidative enzyme activity and copper content in plasma, liver muscles and feces of growing NZW rabbits.

\begin{tabular}{lccccccc}
\hline Parameters & \multicolumn{9}{c}{ Nano-copper levels (mg/kg) } & & \\
\cline { 3 - 6 } & & $\mathbf{0}$ & $\mathbf{2 5}$ & $\mathbf{5 0}$ & $\mathbf{7 5}$ & SEM & Sig. \\
\hline Superoxide dismutase (u/ml) & $103.90^{\mathrm{b}}$ & $140.57^{\mathrm{ab}}$ & $195.88^{\mathrm{ab}}$ & $227.90^{\mathrm{a}}$ & 32.11 & $*$ \\
Catalase (mmol/ml) & 20.50 & 28.83 & 28.83 & 34.33 & 4.33 & $\mathrm{NS}$ \\
Copper & Plasma (mg/dl) & 0.06 & 0.09 & 0.10 & 0.12 & 0.01 & $\mathrm{NS}$ \\
& Liver(mg/kg) & $1.75^{\mathrm{b}}$ & $1.99^{\mathrm{b}}$ & $2.22^{\mathrm{ab}}$ & $2.91^{\mathrm{a}}$ & 0.25 & $*$ \\
& Muscles (mg/kg) & 0.73 & 0.85 & 0.86 & 0.87 & 0.13 & $\mathrm{NS}$ \\
& Feces (mg/kg) & 10.62 & 11.32 & 13.24 & 18.01 & 0.33 & $* *$ \\
\hline
\end{tabular}

SEM = Standard error of means, Sig. $=$ significance $^{\mathrm{a}, \mathrm{b}, \mathrm{c}}$ Means in the same row the different superscript are significantly different $(\mathrm{P}<0.05)$.**: Significant at $0.01 \%$ level of probability, *: Significant at $0.05 \%$ level of probability, NS: Non-significant

in rabbits fed Nano-Cu compared to control group. A similar trend was observed by Grobner et al. (1986) and Adu and Egbunike (2010). The present study also showed that copper residues were greater in liver than in muscles. This result is in line with finding of Valenzuela et al. (2011) who showed that liver of rabbits had the highest $\mathrm{Cu}$ content. Nano-Cu supplementation had no significant effect on $\mathrm{Cu}$ concentration in plasma and muscles (Table 4). This mean that levels of Nano-Cu addition did not 
exceed the permissible limits. Besides that, we can recommend to get rid of liver organ from rabbits received Nano-Cu.

\section{Microbiological assays:}

Caecum content and microbial activity of growing NZW rabbits are presented in Table 5. Dietary Nano-Cu supplementation increased the population of total bacterial count and lactolacillus and decreased the population of E. coli and clostridium spp. in ceacum digesta, especially with $50 \mathrm{mg} / \mathrm{kg}$ of Nano-Cu. Compared with the control group, the population of Lactobacillus in $50 \mathrm{mg} / \mathrm{kg}$ of Nano-Cu supplemented group were increased by 3 folds and the population of E.coli and clostridium were decreased by $63.9 \%$ and $64.1 \%$, respectively. Likewise, Wang et al. (2011) showed that dietary supplementation with Nano-Cu increased Lactobacillus count. It is well known that the intestinal microbiota plays a vital role in nutritional and immunological functions of the host animals (Rehman et al., 2008). The lactobacillus in animal intestines is beneficial to the hosts, whereas coliforms are harmful (Santos et al., 2006). This result may be due to that Nano-Cu establish a better environment for the growth of Lactobacillus (Han et al., 2010). Also, Nanoparticles constitute another group of potent antimicrobials that have already been applied in medicine and pharmacology (Monteiro et al., 2009). In our present microbiological assays, the effects of 50 and $75 \mathrm{mg} / \mathrm{kg}$ of Nano-Cu supplementation were similar. However, more research is needed.

\section{Hematological response:}

Results in Table 6 show that, values of blood picture including $\mathrm{Hb}$, $\mathrm{PCV}, \mathrm{RBCs}, \mathrm{MCH}, \mathrm{MCHC}$ and lymphocyte were significantly higher $(\mathrm{P} \leq 0.05)$ in Nano-Cu supplemented growing rabbits than those of the control group. However, these values are still within the normal ranges. These results disagreed with the reports of Adu (2004) and Ahmed et al. (1997) who reported that diets supplemented with copper had no effects on blood values when fed to rabbits. There were no significant differences $(\mathrm{P} \leq 0.05)$ observed for WBCs level among the experimental groups.

Hemoglobin values were increased (within a normal range) due to addition of Nano-Cu. This may be due to the result of subsequent production of more copper transporting protein ceruloplasmin, which is required for the normal RBC formation by allowing more iron absorption from the small intestine and release of iron from the tissue into the blood plasma as observed by Cromwell et al., (1989). Ceruloplasmin had been 
Table 5: Effect of dietary nano copper supplementation on caecum content and microbial activity of growing NZW rabbits.

\begin{tabular}{|c|c|c|c|c|c|c|}
\hline \multirow{2}{*}{ Parameters } & \multicolumn{4}{|c|}{ Nano copper levels (mg/kg) } & \multirow[b]{2}{*}{ SEM } & \multirow[b]{2}{*}{ Sig. } \\
\hline & $\mathbf{0}$ & 25 & 50 & 75 & & \\
\hline pH & $6.87^{\mathrm{a}}$ & $6.57^{\mathrm{ab}}$ & $6.20^{\mathrm{b}}$ & $6.17^{\mathrm{b}}$ & 0.18 & $*$ \\
\hline $\mathrm{NH}_{3}(\mathrm{mmol} / \mathrm{l})$ & $13.19^{\mathrm{a}}$ & $10.77^{\mathrm{b}}$ & $9.74^{\mathrm{b}}$ & $9.68^{\mathrm{b}}$ & 0.38 & $* *$ \\
\hline Total bacterial count $\left(10^{6}\right)^{(1)}$ & $9.20^{c}$ & $13.13^{\mathrm{bc}}$ & $18.87^{\mathrm{a}}$ & $17.77^{\mathrm{ab}}$ & 1.35 & $* *$ \\
\hline Ureolytic bacteria $\left(10^{5}\right)^{(1)}$ & $3.23^{\mathrm{a}}$ & $2.70^{\mathrm{a}}$ & $1.08^{\mathrm{b}}$ & $1.13^{\mathrm{b}}$ & 0.22 & $* *$ \\
\hline Lactobacilli $\left(10^{5}\right)^{(1)}$ & $3.27^{\mathrm{c}}$ & $5.87^{\mathrm{b}}$ & $9.37^{\mathrm{a}}$ & $9.47^{\mathrm{a}}$ & 0.35 & $* *$ \\
\hline Escherichia coli $\left(10^{4}\right)^{(1)}$ & $6.93^{\mathrm{a}}$ & $4.36^{\mathrm{b}}$ & $2.50^{\mathrm{b}}$ & $2.68^{\mathrm{b}}$ & 0.54 & $* *$ \\
\hline Clostridium spp. ${ }^{(1)}$ & $4.37^{\mathrm{a}}$ & $3.27^{\mathrm{a}}$ & $1.57^{\mathrm{b}}$ & $1.53^{\mathrm{b}}$ & 0.43 & $* *$ \\
\hline
\end{tabular}

Table 6: Effect of dietary nano copper supplementation on blood hematological values of growing NZW rabbits.

\begin{tabular}{|c|c|c|c|c|c|c|}
\hline \multirow[t]{2}{*}{ Parameters } & \multicolumn{4}{|c|}{ Nano copper levels (mg/kg) } & \multirow[t]{2}{*}{ MSE } & \multirow[t]{2}{*}{ Sig. } \\
\hline & $\mathbf{0}$ & 25 & 50 & 75 & & \\
\hline Hemoglobin (g/ dl) & $12.13^{\mathrm{b}}$ & $12.4^{\mathrm{ab}}$ & $12.66^{\mathrm{ab}}$ & $13.56^{\mathrm{a}}$ & 0.356 & $*$ \\
\hline PCV (\%) & $30.6^{\mathrm{c}}$ & $32.41^{\mathrm{c}}$ & $33.46^{\mathrm{b}}$ & $38.7^{\mathrm{a}}$ & 0.155 & $*$ \\
\hline $\operatorname{RBCs}\left(10^{6} / \mu \mathrm{l}\right)$ & $5.19^{\mathrm{b}}$ & $5.89^{\mathrm{a}}$ & $6.05^{\mathrm{a}}$ & $6.18^{\mathrm{a}}$ & 0.144 & * \\
\hline $\operatorname{MCV}^{(1)}(\mathbf{f l})$ & $59.75^{\mathrm{d}}$ & $66.83^{c}$ & $67.1^{\mathrm{b}}$ & $67.76^{\mathrm{a}}$ & 0.078 & $*$ \\
\hline $\mathrm{MCH}^{(2)}(\mathrm{pg})$ & $19.5^{\mathrm{d}}$ & $21.8^{\mathrm{c}}$ & $22.26^{\mathrm{b}}$ & $22.6^{\mathrm{a}}$ & 0.088 & $*$ \\
\hline $\operatorname{MCHC}^{(3)}(\mathrm{g} / \mathrm{l})$ & $32.5^{\mathrm{c}}$ & $32.86^{b}$ & $33^{\mathrm{b}}$ & $34.36^{\mathrm{a}}$ & 0.074 & * \\
\hline WBCs $\left(10^{3} / \mu \mathrm{l}\right)$ & 6.08 & 7.25 & 7.87 & 8.4 & 2.511 & NS \\
\hline Lymphocytes (\%) & $44.73^{\mathrm{d}}$ & $47.73^{c}$ & $48.73^{b}$ & $55.45^{\mathrm{a}}$ & 0.302 & $*$ \\
\hline
\end{tabular}

SEM = Standard error of means, Sig. = significance ${ }^{a, b, c}$ Means in the same row the different superscript are significantly different $(\mathrm{P}<0.05)^{*}$ : Significant at $0.05 \%$ level of probability, NS: Non-significant (1) Mean corpuscular volume , (2) Mean corpuscular hemoglobin

(3) Mean corpuscular hemoglobin concentration

reported to play a critical role in the haematopoietic process, by facilitating the mobilization of iron from the reticuloendothelial cells of the liver and spleen to the bone marrow cells and by catalyzing the oxidation of ferrous iron ions during the formation of ferritransferrin (Freiden and Hsieh, 1976). Bassuny (1991) reported similar result in rabbits, where the values of the $\mathrm{RBC}$ and $\mathrm{Hb}$ were higher in animals fed dietary copper than the control. Also, Dorton et al. (2003) concluded that dietary supplementation with copper could stimulate body immune system. 


\section{Economical efficiency:}

Effect of Nano-Cu supplementation at different levels are shown in Table 7. Rabbits fed basal diet supplemented with either 50 or $75 \mathrm{mg}$ Nano$\mathrm{Cu} / \mathrm{kg}$ diet recorded high economical efficiency (107.9 and 104.5\%), respectively compared with the control group. These results were in accordance with Ayyat (1995) who observed that addition of 100 or $200 \mathrm{mg}$ copper in rabbit diets increased final, margin with 27.0 and $51.7 \%$, respectively than the control diet.

\section{Table 7: Effect of dietary nano copper supplementation on} economical traits of NZW rabbits at 13 wks of age.

\begin{tabular}{|c|c|c|c|c|}
\hline \multirow{2}{*}{ Parameters } & \multicolumn{4}{|c|}{ Nano copper levels ( $\mathrm{mg} / \mathrm{kg})$} \\
\hline & $\mathbf{0}$ & 25 & 50 & 75 \\
\hline Average feed intake (kg /head) & 4.42 & 4.34 & 4.30 & 4.24 \\
\hline Price /kg diet (L.E.) & 2.25 & 2.30 & 2.35 & 2.40 \\
\hline Total feed cost (L.E.) & 9.96 & 9.98 & 10.11 & 10.18 \\
\hline Average weight gain (kg/head) & 1.31 & 1.30 & 1.39 & 1.36 \\
\hline Selling price $(\text { L.E.E. })^{(1)}$ & 35.37 & 35.10 & 37.53 & 36.72 \\
\hline Net revenue (L.E.. $)^{(2)}$ & 25.41 & 25.12 & 27.42 & 26.54 \\
\hline Relative revenue (\%) & 100 & 98.86 & 107.91 & 104.45 \\
\hline
\end{tabular}

Other conditions like management are fixed.

- Ingredients price (L.E. per ton) at 2013 were: 2500 yellow corn; 3000 barley; 1500 berseem hay;

1800 wheat bran; 3750 soybean meal $(44 \%) ; 4000$ soybean meal $(48 \%) ; 250$ limestone; 9000

premix; 40000 methionine; 21000 lysine; 1000 di-calcium phosphate; 1000 molasses; 250 salt;

13000 choline chloride; 5000 antioxidant.

- Adding 100 L.E. /ton for pelliting.

(1) Price of kg live body weight was 27 L.E.

(2) Net revenue $=$ Selling price - total feed cost

Conclusively, the present results indicated that the supplementation of Nano-Cu can improve growth performance, influence intestinal microbiota, and improve economical efficiency, especially with the supplementation of $50 \mathrm{mg} / \mathrm{kg}$, and Nano-Cu could be a new substitute for high dose of inorganic copper.

\section{REFERENCES}

Aboul-Ela, S., Abd EL - Galil K., Alif .A., (2000). Effect of dietary fiber and energy levels on performance of post-weaning rabbits. World Rabbit Sci., 8 ( Suppl.1), 61 - 75. 
Adu, O.A. and Egbunike, G.N. (2010). Enhancing Growing Rabbits Performance with Diets Supplemented with Copper. Advances in Biological Research, 4 (1): 18-22.

Adu, O.A. (2004). Performance, Haematology and Sperm production of growing male rabbits fed diets with different levels of copper sulphate. M. Sc. Dissertation, Dept. of Animal Science, University of Ibadan, Ibadan.

Adu,O. A; Akinfemi, A. and Adebiyi, O. A. (2010). effect of varied levels of dietary copper on performance and blood chemistry of growing female rabbits. Tropical and Subtropical Agroecosystems, 12: $313-319$.

Ahmed, H., Syah, D., Ter Merulen, U. and Hermis, I. (1997). Effect of using copper Sulphate as a feed additive on the productivity performance in growing rabbits. Tropentag Hohenheim, 177-180.

Alves, A., Pinheiro, V., Mourao, J. L., Pires I., Oliveira, J., Gama,A. (2004). Measurement of rabbits intestinal villus: preliminary comparison of two methods. 8th World Rabbit Congress, September 7-10, 2004 - Puebla, Mexico

Ansari, M., and Raissy, M. (2011). Determination of Copper, Iron and Zinc in the Muscles of Fresh water Fish from Beheshtabad River. Global Veterinaria, 7 (5): 502-505.

Ayyat, M.S. (1995). Effect of different levels of dietary protein and copper on growth performance in rabbits. Egypt. J. Rabbit Sci., 4 (1): 83-92.

Ayyat, M.S., Marai, I.F.M. and Alazab, A.M. (1995). Copper-protein nutrition of New Zealand white rabbits under Egyptian conditions. Wld. Rabbit Sci., 3 (3): 113-118.

Bassuny, S.M. (1991). The effect of copper supplementation on rabbit performance under Egyptian conditions. Journal of Applied Rabbit Research, 14:93-97.

Benson, H.J; Gunstream, S.E; Talaro, A and Talaro, K. P. (1989). Anatomy and Physiology Laboratory Textbook. Win. C. Brown Publisher Dubuque, IOWA.

Berntssen M.H. Hylland, G, K., Wenderlaar Bonga, S.E. and Maage, A. (1999). Toxic levels of dietary copper in Atlantic salmon. Aquat. Toxicol., 46:87-99.

Cheeke, P.R. (1987). In: Rabbit feeding and Nutrition. Academic Press, San Diego. 
Collins, C.H.; Lyne, P.H. and Grange, J.M. (1995). Collins and Lyne's microbiological methods. Butterworth heinemann ltd, oxford.

Conway, E.J.(1958). Micro Diffusion Analysis And Volumetric Error, $4^{\text {th }}$ ed. The Mc-Millan Co., New York, USA, 687 p.

Cromwell, G.L, T.S. Stalily and H.J. Monegue (1989). Effect of source and level of Copper on performance and liver copper stores in weanling pigs. J. Anim. Sci., 67: 2996-3002.

Dorton, K.L., T.E. Engle, D.W. Hamar, P.D. Siciliano and R.S. Yemm. (2003). Effects of copper source and immune function in growing and finishing steers. Animal Feed Science and Technology, 110:31.

Du, W. L. (2008). Antibacterial activity of aminopolysaccharide nanoparticles loaded metal ions and its effects on the immune function in rats. Ph D Dissertation. Zhejiang University, Hang- zhou, Zhejiang Province, China.

Duncan, D.B.(1955). Multiple range and multiple F tests. Biometrics, 11: 1-42.

EU Council Directive 70/524/EEC. (2003). Opinion of the scientific committee for animal nutrition on the use of copper in feeding stuffs. (European Commission Health and Consumer Protection Directorate General). Pp: 1-3e.

Fahmy B, and Cormier S.A.(2009). Copper oxide nanoparticles induce oxidative stress and cytotoxicity in airway epithelial cells. Toxicol In Vitro, 23(7): 1365-1371.

Freiden, E. and Hsieh, H. S. (1976). Ceruloplasmin. The copper transport protein with essential oxidase activity. In. Meister, A; ed; Advances In Enzymology And Related Areas Of Molecular Biology, Vol. 44: 187-236.

Gonzales-Eguia A., Chao-Ming F. B, Fu-Yin L.C., Lien, T. F. (2009). Effects of nanocopper on copper availability and nutrients digestibility, growth performance and serum traits of piglets. Livestock Science, 126 : 122-129.

Grobner, N.A., Cheeke P.R., and Patton, N.M. (1986). Effect of dietary Copper and oxytetracycline on growth and motality of wean rabbit. J. of Appl. Res., 9: 46-53.

Han, X.Y., Du, W. L. Fan, C. L. and Xu, Z. R. (2010). Changes in composition a metabolism of caecal microbiota in rats fed diets supplemented with copper-loaded chitosan nanoparticles. J. Anim. Physiol. Anim. Nutr. (Berl.) 94:e138-e144. doi:10.1111/ j.14390396.2010.00995.x. 
Hedemann, M.S., and Jensen B.B. (2004). Variations in enzyme activity in stomach and pancreatic tissue and digest in piglets around weaning. Arch Anim. Nutr., 58(1): 47-59.

Hussain, N., Jaitley, V., and Florence, A.T. (2001). Recent advances in the understanding of uptake of microparticles across the gastrointestinal lymphatics. Adv. Drug Deliv. Rev., 50:107-142.

Idowu, O.M.O.; Ajuwon O.R., Fafiolu, A.O., Oso, A.O., and Akinloye, O.A. (2011). Modulation of cholesterol and copper residue levels in muscles and blood serum of finishing broiler chickens fed copper and ascorbic acid supplements. Pak. J. Nutr., 10 (8): 781-785.

Jain, N.C. (1986). Schalms Veterinary Haematology.4th Ed. Eea and Febiger, philadelphia, USA.

Kim, H.U. and Goepfert, J.M. (1971). Enumeration and identification of bacillus cereeus in foods. 1,24-hours presumptive test edium. Appl. Microbiol., 22:581-587.

Lamb, G.M. (1981). Manual of Veterinary Laboratory Rabbit. Techniques. Ciba-Geigy, Kenya.

Laurence D., Isabelle, L.H., Thierry, G., Laurence, F.L. (2003). Digestive tract development in rabbit according to dietary energetic source: correlation between whole tract digestion, pancereatic and intestinal enzymatic activities. Comp. Biochem. Phys., A., 135: 443455.

Lien, T.F. (2009). Nanosize of copper sulfate and effects on growth, copper availability, and excretion of pigs. Liv. Res. Int., 1: 30-36.

McCracken, B.A.; Spurlock, M.E., Roos, M.A., Zuckermann, F.A., and Gaskins, H.R. (1999). Weaning anorexia may contribute to local inflammation in piglet small intestine. J. Nutr.,129:613-619.

McDonald, P., Edwards, R.A. , Greenhalg, J.F.D. and Morgan, C.A. (2002). Animal Nutrition. 6th Ed., Pearson Education, Harlow.

McDowell, L.R..(1992). Mineral In Animal And Human Nutrition. Academic Press Inc., San Diego, New York, Boston, London, Sydney, Tokyo, Toronto, pp: 524.

Monteiro D.R., Gorup, L.F., Takamiya, A.S. Ruvollo-Filho, A.C. de Camargo, E.R., and Barbosa, D.B. (2009). The growing importance of materials that prevent microbial adhesion; antimicrobial effect of metal devices containing silver. Int. J. Antimicrob. Agents, 34: 103-110. 
NANO-COPPER AS A NEW GROWTH PROMOTER IN DIET RABBITS 55

Nickkels, R.J., Mullink, J.W., and Van Vliet J.C. (1976). An outbreak of rabbit enteritis: pathological and microbiogical findings and possible therapeutic regime. Lab Anim.; 10(3):195-198.

North, M. O.(1981). Commercial Chicken Production. Annual. $2^{\text {nd }}$ Edition, Production $6^{\text {th }}$ Ed. Interstate Printers and Publishers. INC., USA.

NRC (1977). National Research Council. Nutrient Requirements of Domestic Animal. Nutrient Requirement of Rabbits. Washington, U.S.A.

Onifade, A.A., and Abu, O.A. (1998). Productive response of rabbits to supplemental copper in a diet based on tropical feedstuffs. J. Appl. Anim. Res., 13: 129- 135.

Patton, N.M., Aris, D.J. Grobner, N.A. Swick, R.A. and Cheeke, P.R. (1982). Effect of dietary copper sulphate on enteritis in frier rabbit. J. of Appl. Res: 5: 78-82.

Rajendran, D. (2013). Application of nano minerals in animal production system. Res. J. Biotech., 8: 1-3.

Rehman, H., Hellweg, P. Taras, D. and Zentek, J.(2008). Effects of dietary inulin on the intestinal short chain fatty acids and micro- bial ecology in broiler chickens as revealed by denaturing gradient gel electrophoresis. Poult. Sci., 87:783-789.

Sahoo, S.K. and Labhasetwar,V. (2003). Nanotech approaches to drug delivery and imaging. Drug Discov. Today, 73:1112-1120.

Santos, A., Mauro, M. S. and Diaz, D. M.( 2006). Prebiotics and their long-term influence on the microbial populations of the mouse bowel. Food Microbiol., 23:498-503.

SAS Statistical Analysis System (2001). User's Guide Version 8.2, Cary NC. USA.

Shurson, G.C., Ku, P.K Warler, G.L Yokoyama, M.T. and Miller, E.R. (1990). Physiological relationships between microbiological status and dietary copper in the pig. J. Animal Sci., 68: 1061-1071.

Shurson, G.C.; Ku, P.K. Waxler, G.L. Yokoyama, M.J. and Miller, E.R. (1987). In "Trace Element Metabolism In Man And Animals". Plenum Press, New York. Pp. 53.

Underwood, E.J. and Suttle, N.F. (1999). Copper In: The Mineral Nutrition Of Livestock. Ed.3., CABI Publishing, Walling ford, UK, 283-342. 
Valenzuela, C., de Romaña, D.L., Schmiede, C., Morales, M.S., Olivares, M., and Pizarro, F. (2011). Total iron, heme iron, zinc, and copper content in rabbit meat and viscera. Biol. Trace. Elem. Res., 143:1489-96.

Wang, C., Wang, M. Q., Ye, S. S., Tao ,W. J., and Du, Y. J. (2011). Effects of copper-loaded chitosan nanoparticles on growth and immunity in broilers. Poultry Science, 90 :2223-2228.

Warren, J.E. and Gregory, G. (2005). Statistical Methods in Bioinformatics: An Introduction (Statistics for Biology and Health). Springer Science Press, New York, USA.

Yassein, S.A., Abdel-Aziem, S.H., El-Mallah, G.M. and Maghraby, N.A. (2011). Response of growing rabbits to feed restriction and some additives on performance, carcass and hepatic gene expression under Egyptian summer conditions. J. Agric. Sci., 3 (2): 45-55.

Zhang, H. X., Siegert, U., Liu, R. and Cai, W.B. (2009). Facile Fabrication of Ultrafine Copper Nanoparticles in Organic Solvent, Nanoscale Res Lett. (4): 705-708.
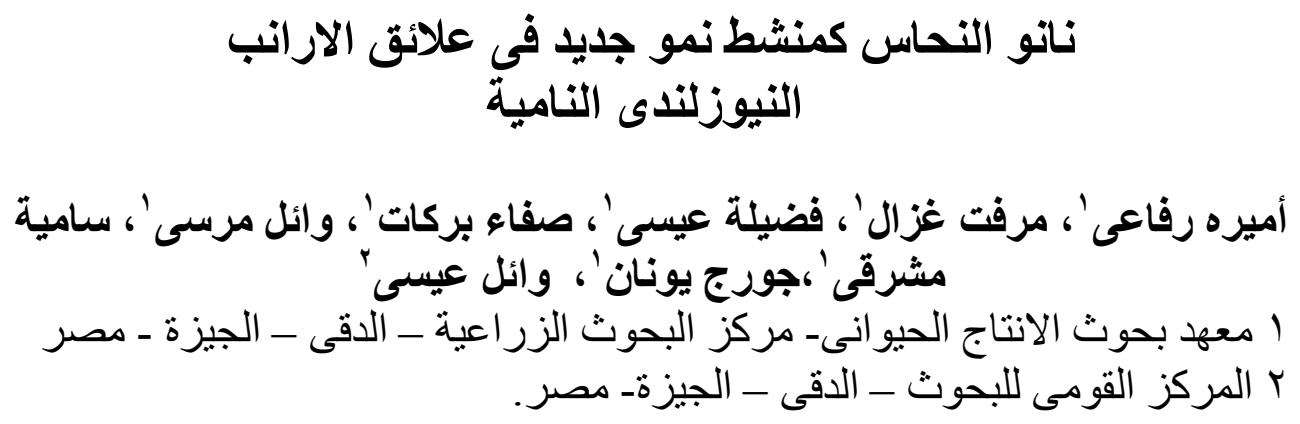

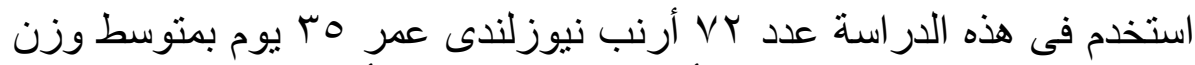

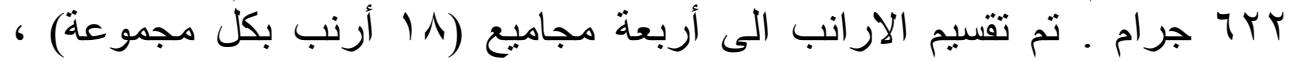

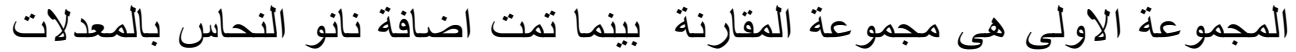

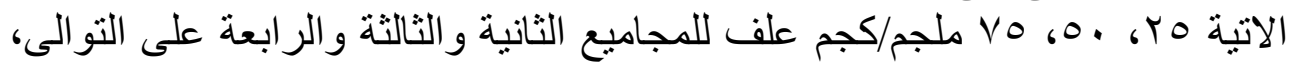
وقد استمرت تجربة التغذية لمدة ه $\wedge$ أسابيع.

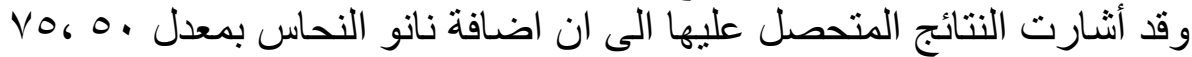

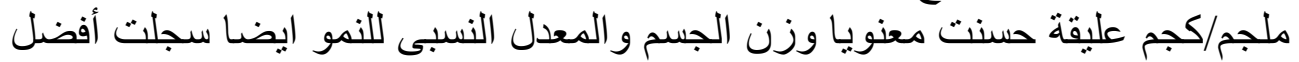


NANO-COPPER AS A NEW GROWTH PROMOTER IN DIET RABBITS 57

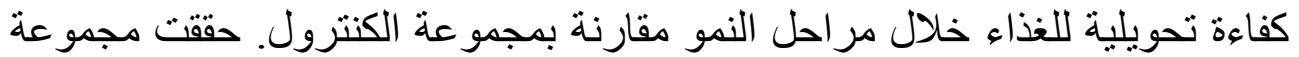

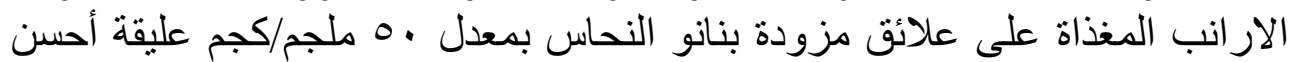

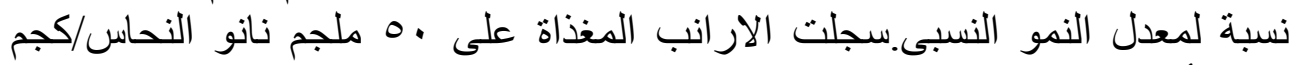

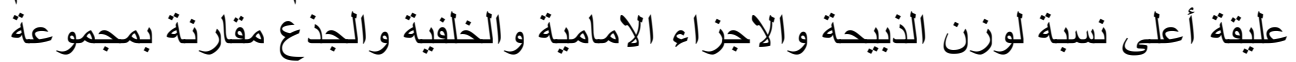

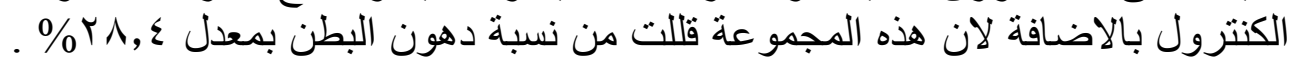

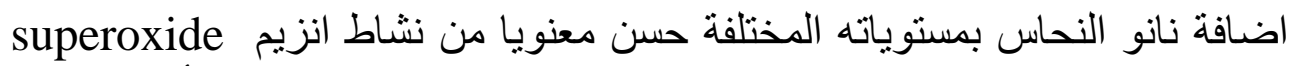
dismutase .ureolytic, Escherichia coli clostridium spp

ز اد تركيز النحاس فى كبد الار انب معنويا بزيادة نسبة نانو النحاس فى العليقة.

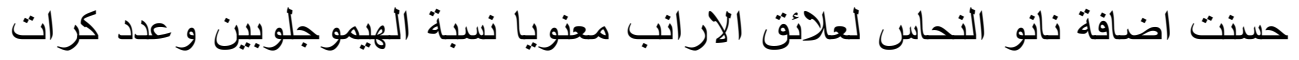

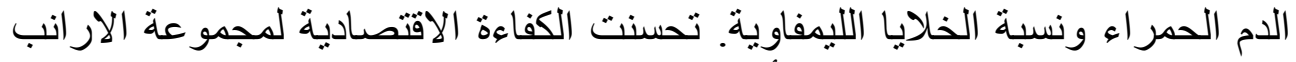



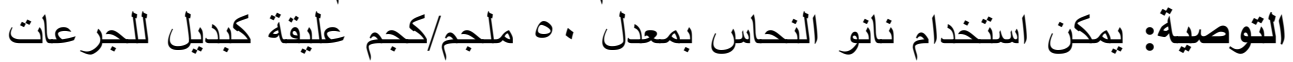
العالية من المصادر الاخرى للنحاس فى علائق الار انب النيوزلندى النامية. 